\title{
Ei-tietoinen kognitio monitieteisenä \\ käsitteenä
}

\section{Hayles, N. Katherine, Unthought: The Power of the Cognitive Nonconscious. Chicago: University of Chicago Press, 2017, 272 S.}

Romaanissaan Kuumalinja (1995, alk. Hotwire, 1993) brittikirjailija Simon Ings visioi San Fransiscon puhelinverkkoa, joka kehittyy hermoverkon lailla: mitä enemmän kytköksiä - siis soittoja - sitä voimakkaammaksi verkon kognitio kehittyy. Pieni aktivistiryhmä odottaa kaupungin heräämistä tietoisuuteen ja kannustaa sitä soittamalla puhelinkopeista satunnaisia soittoja.

Internetin alkuvuosista on tultu pitkälle, mutta fantasia tietoisuuteen heräävästä tietoteknologiasta elää vahvana. Ingsin teoksessa kognitiivinen toimija oli kaupungin kokoinen järjestelmä, jonka aavistuksista ja pyrkimyksistä ihmiset eivät kuvitelleetkaan saavansa täyttä selkoa. Suurissa scifituotannoissa ja julkisessa keskustelussa tekoälyn ja autonomisten koneiden etiikkaa lähestytään kuitenkin usein näkökulmasta, joka pyrkii tekemään koneesta tai ohjelmistosta yksilöllisen, potentiaalisesti tietoisen toimijan: mitä itseohjautuva auto miettii valitessaan, ajaako lapsen päälle vai syöksyäkö jyrkänteeltä?

Kirjallisuudentutkija N. Katherine Hayles pitää yksilö- ja tietoisuuskeskeistä keskustelua koneellisesta kognitiosta harhaanjohtavana. Teoksessaan Unthought Hayles argumentoi, että tietoisuuden pohdiskelun sijaan tutkimuksen olisi syytä keskittyä perusteellisemmin teknisten järjestelmien ei-tietoiseen ja systeemiseen kognitioon - siis sellaiseen kognitioon, joka jo vaikuttaa kaikkiin ihmiselämän osa-alueisiin.

Hayles vetää yhteen kognitiotutkimuksen ja koneellisen kognition kehityskulkuja ja perustelee kärsivällisesti, miksi humanistin pitäisi kiinnostua niistä. Samalla hän ottaa kantaa posthumanistisen teorian ja digitaalisten ihmistieteiden nykysuuntauksiin. Ennen kaikkea teos on kuitenkin Haylesin oman teoreettisen mallin esittely ja puolustus: se hahmottelee ei-tietoisen kognition (nonconscious cognition) käsitettä ja perustelee, kuinka sitä voi käyttää kuvailemaan niin ihmismielen, muiden biologisten lajien kuin teknisten järjestelmienkin kognitiivisia prosesseja. Ihmisessä ei-tietoinen kognitio pitää huolta tärkeistä toiminnoista, kuten ympäristön monitoroinnista ja ruumiillisesta ymmärryksestä. Ei-tietoinen kognitio on näin ollen paljon laajempi käsite kuin psykoanalyyttinen "tiedostamaton": se käsittää tiedostamattomien muistojen ja kokemusten lisäksi ruumiillisen toiminnan jatkuvan ylläpidon.

Hayles pyrkii eroon älykkyyden ja ajattelun kaltaisista ihmiskeskeisistä käsitteistä. Hänen kognition käsitteensä onkin hyvin laaja: se käsittää "pro- 
sesseja, joissa informaatiota tulkitaan konteksteissa, joissa ne yhdistyvät merkitykseen” (22). Tämä määritelmä nojaa etenkin kognitiobiologiaan, jossa kognitiivinen toiminta nähdään kaikille elämänmuodoille ominaisena: määritelmän mukaisesti bakteerit ja solukalvotkin toimivat kognitiivisesti tehdessään valintoja siitä, mitä päästää sisäänsä ja mitä pitää ulkona. Haylesin malli ei kuitenkaan jäsennä elämän ja kognition keskinäistä suhdetta, joten on vaikea sanoa, lähestyykö malli vaikkapa mielenfilosofi Evan Thompsonin teoksessaan Mind in Life (2007) radikaalia määritelmää, jossa "elämä on mieltä ja mieli on elämää” - ja voidaanko teknisiäkin järjestelmiä pitää tässä mielessä elävinä.

Hayles ehdottaa, että ei-tietoisen kognition käsite voi auttaa jäsentelemään kognitiivisia sommittumia (cognitive assemblages): järjestelmien, alajärjestelmien ja yksittäisten toimijoiden muodostamia kokonaisuuksia, joiden läpi informaatio virtaa. Sekä inhimilliset että ei-inhimilliset kognitiiviset toimijat tulkitsevat informaatiovirtoja ja aiheuttavat siten muutoksia sommittuman osasissa. Hayles nostaa esimerkeiksi kognitiivisista sommittumista liikenteenohjauksen, autonomisen taistelulennokit konteksteineen ja pörssisijoittamisen. Hän kritisoi tiukkaan sävyyn etenkin kahden jälkimmäisen sommittuman nykytilaa ja penää niiden kehitykseen ja tutkimukseen "lisää ihmiskognitiota". Vaarallista ei ole niinkään koneen kognitiivinen kyvykkyys vaan se, että ihmiset eivät tunnista ja analysoi yhteenkietoutuneisuuttaan teknisten järjestelmien kanssa.

Hayles korostaa, että hän ei hahmota ihmismielen ei-tietoista kognitiota ja teknistä ei-tietoista kognitiota keskenään identtisiksi prosesseiksi. Niiden fyysiset ja materiaaliset kontekstit ovat keskenään hyvin erilaisia. Kuitenkin ihmismielen ja teknisten järjestelmien kognitiivisissa prosesseissa on niin paljon rakenteellista ja funktionaalista samankaltaisuutta, että niitä voidaan perustellusti käsitellä samalla käsitteellisellä apparaatilla.

Yksi Unthoughtin arvokkaimmista antimista on siinä muotoiltu uusmaterialismin kritiikki. Haylesin mukaan uusmaterialistinen teoriasuuntaus on materiaalista toimijuutta teoretisoidessaan sivuuttanut kognition täysin. Eitietoisen kognition malli taas määrittää eroja materiaalisen toimijuuden eri muotojen välille ja erottaa kognitiivisen toimijuuden omaksi osa-alueekseen. Materiaalinen toimijuus voi Haylesin mukaan olla vaikutuksiltaan täysin determinististä (esim. kivi, joka rikkoo ikkunan), ei-lineaarista ja siksi ennalta-arvaamatonta (esim. lumivyöry), itsejärjestäytyvää (esim. elämän synty maapallolla) tai kognitiivista toimintaa edeltävää ja tukevaa. Kognitiivisissa toimijoissa on erityistä se, että ne muokkaavat ympäristöään tekemällä valintoja ja tulkintoja.

Toimijuuden määrittely tällaisella jatkumolla on Haylesin mukaan tärkeää erityisesti siksi, että se toimii vastavoimana deleuzelaiselle "voimien, intensiteettien ja sommittumien" ajattelulle. Deleuzelainen käsitteistö haastaa ja purkaa merkitysrakenteita, joissa kaikki pyörii selkeästi rajattujen kappaleiden ja yksilösubjektien ympärillä. Hayles kuitenkin haluaisi uusmaterialistien tunnustavan, että materiaalinen todellisuus sisältää myös kappalemaisia ja 
hierarkkisia järjestyksiä, joiden hahmottamiseen tarvitaan analyyttisia kategorioita ja malleja. Tässä linjauksessa näkyy esimerkiksi Haylesin How We Became Posthuman -teoksessaan (1999) perkaama järjestelmäteoreettinen ajattelu.

Vaikka Hayles on taustaltaan kirjallisuudentutkija, jää jossain määrin epäselväksi, millä tavoin kirjallisuudentutkimus voisi parhaiten hyödyntää teoksessa esiteltyjä jäsennyksiä. Hayles analysoi romaaneja, mutta tulkinnan anti jää lähinnä temaattiseksi. Teoksen loppupuolella hän esittää lukuisia ehdotuksia siitä, miten perinteinen kertomakirjallisuuden tutkimus voisi tarttua ei-tietoiseen kognitioon, mutta ei havainnollista näitä ehdotuksia luennalla. Syynä on ehkä Unthoughtille toivottu monialainen lukijakunta. Haylesin aiempi tutkimus, esimerkiksi teokset How We Think: Digital Media and Contemporary Technogenesis (2012) ja Electronic Literature: New Horizons for the Literary (2008), tarttuu kirjallisuuden muodon ja vastaanoton kysymyksiin tarkemmin erityisesti digitaalisen kirjallisuuden kontekstissa. Koneellisesti avustettu lukeminen onkin hyvä esimerkki kognitiivisesta sommittumasta: algoritmi löytää tekstiaineistoista erilaisia asioita kuin tietynlaisiin merkityksiin taipuvainen ihmislukija, ja yhdistämällä koneen ja ihmisen lukutapoja voidaan tuottaa rikkaampia tulkintoja.

Olisi kiinnostavaa lukea tutkimusta, joka ottaa Haylesin ei-tietoisen kognition mallin tosissaan. Mallilla voisi olla paljon annettavaa erityisesti ruumiillisen ja ympäristöllisen mielen teorioista ja affektiteoriasta ammentaville tutkijoille. Ei-tietoisen kognition ja kognitiivisen sommittuman käsitteitä voisi soveltaa myös muista biologisista elämänmuodoista kiinnostuneessa posthumanistisessa tutkimuksessa. Mitä uutta ei-tietoisen kognition näkökulma voisi tuoda vaikkapa kumppanilajien tutkimukseen? Voitaisiinko tutkia, miten teknisten järjestelmien kognitio toimii osana monilajisia kognitiivisia ekologioita? Muuttuisiko kaupunkisuunnittelu, jos puistojen puita ja valkoposkihanhien parvia ajateltaisiin kognitiivisina eikä vain ekologisina toimijoina?

\section{Kaisa Kortekallio}

